\title{
Highly-polar Layered Double Hydroxides are Efficient Adsorbents of Low- concentrated Trihalomethanes Present in Water
}

\author{
Alejandra Morales ${ }^{1}$, Magali Hernández ${ }^{1}$, Erik Pérez ${ }^{1}$, Ariel Guzmán ${ }^{2}$, Enrique Lima ${ }^{1, *}$ \\ ${ }^{1}$ Laboratorio de Fisicoquímica y Reactividad de Superficies (LaFReS), Instituto de Investigaciones en \\ Materiales, Universidad Nacional Autónoma de México, Circuito exterior s/n, Cd. Universitaria, Del. \\ Coyoacán, CP 04510, Ciudad de México, Mexico \\ ${ }^{2}$ Instituto Politécnico Nacional - ESIQIE, Avenida IPN UPALM Edificio 7, Zacatenco, 07738 México D.F., \\ Mexico \\ * Corresponding author: Phone: +52 (55) 5622 4640, Fax: +52 (55) 5616 1371, E-mail: \\ lima@iim.unam.mx
}

Received May $7^{\text {th }}, 2018$; Accepted June 25 2018.

DOI: $\underline{\text { http://dx.doi.org/10.29356/jmcs.v62i3.557 }}$

\begin{abstract}
Replacement of $\left(\mathrm{Al}(\mathrm{OH})_{6}\right)^{3-}$ blocks by $\left(\mathrm{AlF}_{6}\right)^{3-}$ was explored as a strategy to modify the dipolarity of layered double hydroxides materials (LDHs). The presence of fluorine augments the dipolarity/polarizability of LDHs. LDHs were tested as adsorbents of the trihalomethanes $\mathrm{CHCl}_{3}$ and $\mathrm{CHBr}_{3}$ that are present (low concentrated) in water. Fluorinated LDHs were significantly more efficient compared to that without fluorine. Thermal treated fluorinated LDHs are able to remove $95 \%$ and $90 \%$ of $\mathrm{CHCl}_{3}$ and $\mathrm{CHBr}_{3}$, respectively, present in low concentrated aqueous solutions. The effect of concentration of triahalomethanes, time of contact and structure of adsorbent were explored. Linear isotherms were obtained when un-fluorinated adsorbents were used but the isotherm turns to match that of Freundlich-type when adsorbent contains fluorine.
\end{abstract}

Keywords: Layered double hydroxides; Fluorine; Adsorption; Trihalomethanes; Water pollution.

Resumen. La sustitución de iones de $\left(\mathrm{Al}(\mathrm{OH})_{6}\right)^{3-}$ por $\left(\mathrm{AlF}_{6}\right)^{3-}$ se investigó como una estrategia para modificar la dipolaridad de los hidróxidos dobles laminares (HDL). La presencia de flúor aumenta la dipolaridad / polarizabilidad de los HDL. Los HDL se probaron como adsorbentes de los trihalometanos $\mathrm{CHCl}_{3}$ y $\mathrm{CHBr}_{3}$ presentes a bajas concentraciones en agua. Los HDL fluorados fueron significativamente más eficientes en comparación con los que no contenían flúor. Los HDL fluorados tratados térmicamente pueden eliminar $95 \%$ y $90 \%$ de $\mathrm{CHCl}_{3}$ y $\mathrm{CHBr}_{3}$, respectivamente, presentes en soluciones acuosas a baja concentración. Se examinó el efecto de la concentración de trihalometanos, el tiempo de contacto y la estructura del adsorbente. Se obtuvieron isotermas lineales cuando se usaron adsorbentes no fluorados; en contraste, cuando el adsorbente contiene flúor la isoterma coincide con la de tipo Freundlich.

Palabras clave: Hidróxidos dobles laminares; Flúor; Adsorción; Trihalometanos; Agua contaminada.

\section{Introduction}

The polluted water is the major source of many diseases causing serious health problems [1]. Thus, disinfection is a crucial process reducing the number of pathogenic organisms in order to produce drinking water [2,3]. Chlorination is the largest method used for sewage disinfection. Because of the resistance of some microbes, the required chlorine doses may be high [4]. Thus, the health issues related to its disinfection by- 
products such as trihalomethanes (THM) has been evidenced. It has been found that THM form when food and beverages are prepared using water disinfected with chlorine $[5,6]$. Nevertheless, it is inevitable to continue using chlorine, since the world health organization (WHO) consider more risky stop using it than the effect caused by expositions to THM. The major THMs identified in disinfected water are chloroform $\left(\mathrm{CHCl}_{3}\right)$, bromoform $\left(\mathrm{CHBr}_{3}\right)$ and bromodichloromethane $\left(\mathrm{CHCl}_{2} \mathrm{Br}\right)$ [7]. Because of the presence of chloroform and others THM in drinking water, interest has been increased since point of view of public health which it is necessary to develop new strategies in order have water free of pollutants of this type. In this sense, it has been proved the efficacy of ionic exchange resins to remove ionic THM precursors [8-12]. However, the presence of THM in water is a reality; Therefore, one of the most recommendable strategies is the fabrication of stable solid adsorbents in order to avoid introducing new elements leading to additional pollution of water. In this context, layered doubles hydroxides (LDH) can potentially retain THM. LDHs have the ideal formula $\left[\mathrm{M}^{\mathrm{II}}{ }_{1-\mathrm{x}} \mathrm{M}^{\mathrm{III}}{ }_{\mathrm{x}}(\mathrm{OH})_{2}\right]^{\mathrm{x}+}\left(\mathrm{A}^{\mathrm{n}-}{ }_{\mathrm{x} / \mathrm{n}}\right) \cdot \mathrm{mH}_{2} \mathrm{O}$. Metallic cations $\left(\mathrm{M}^{\mathrm{II}}\right.$ and $\left.\mathrm{M}^{\mathrm{III}}\right)$ are located in coplanar octahedra $\left[\mathrm{M}(\mathrm{OH})_{6}\right]$ sharing edges and forming $\mathrm{M}(\mathrm{OH})_{2}$ layers with the brucite structure [13]. The presence of the $\mathrm{M}^{\mathrm{III}}$ cations as well as $\mathrm{M}^{\mathrm{II}}$ cations induces a positive charge in the layer, which is balanced by the anions between the hydroxylated layers, where water molecules are also present [14,15]. A large family of LDHs has been synthesized as the nature of trivalent and divalent cations in the layers can be changed and the intercalation of a great diversity of interlayer anions [16,17]. The layered structure is lost due to heating at a moderate temperature, often between 350 and $500{ }^{\circ} \mathrm{C}$ [18]. LDHs have found applications mainly as catalysts and adsorbents $[19,20]$.

Recently, the replacement of structural blocks $\left(\mathrm{Al}(\mathrm{OH})_{6}\right)^{3-}$ by $\left(\mathrm{AlF}_{6}\right)^{3-}$ was reported [21] in order to diversify the physicochemical properties of LDH. This fact opened new applications of LDH and enhanced others. As a consequence of the partial replacement of $\mathrm{OH}^{-}$by $\mathrm{F}^{-}$dipoles of different strength appears and the polarity/polarisability at the LDH surface is modified [22]. This modification gives advice that molecules with a dipolar moment such as THM could be easily adsorbed in LDH. Thus, this work started with the goal of exploring the adsorption of THM in LDH and stable fluorinated LDH.

\section{Experimental Procedures}

\section{Materials}

Synthesis of LDHs. Carbonate-containing $\mathrm{Mg}-\mathrm{Al} \mathrm{LDHs}$ with a $\mathrm{Mg} / \mathrm{Al}$ atomic ratio close to 3 were prepared by a sol-gel method. A dissolution of aluminium tri-sec-butoxide (ATB, Aldrich $99.9 \%$ ) in ethanol was refluxed and stirred for $1 \mathrm{~h}$. Afterward the temperature was decreased to $0{ }^{\circ} \mathrm{C}, 3 \mathrm{M} \mathrm{HNO}_{3}$ was dropped, and the mixture was stirred $1 \mathrm{~h}$. Following this, magnesium methoxide (Aldrich, 99\%) dissolved in butanol, and water were slowly dropped into the solution until a gel was formed, which was dried at $70{ }^{\circ} \mathrm{C}$. In the synthesis of fluorinated LDHs, a part of ATB was replaced by sodium hexa-fluoroaluminate, $\mathrm{Na}_{3} \mathrm{AlF}_{6}$ (Aldrich, 99.99\%). The ratio of $\mathrm{Mg} / \mathrm{Al}$ was maintained at 3; the fluorine content was varied according to Table 1. The chemical composition reported in Table 1 is the result obtained from thermal analysis and chemical analysis conducted by inductively coupled plasma-mass spectrometry (ICPMS), where a Thermo Scientific ${ }^{\mathrm{TM}}$ ELEMENT $2^{\mathrm{TM}}$ system was used.

Table 1. Chemical composition of layered double hydroxides used as adsorbents.

\begin{tabular}{|l|l|}
\hline Code Name & Chemical formula \\
\hline HT & {$\left[\mathrm{Mg}_{0.775} \mathrm{Al}_{0.258}(\mathrm{OH})_{2}\right]\left(\mathrm{CO}_{3}\right)_{0.129} 0_{.51 \mathrm{H}_{2} \mathrm{O}}$} \\
\hline HT-10F & {$\left[\mathrm{Mg}_{0.743} \mathrm{Al}_{0.248}(\mathrm{OH})_{1.88} \mathrm{~F}_{0.12}\right]\left(\mathrm{CO}_{3}\right)_{0.124} 0.52 \mathrm{H}_{2} \mathrm{O}$} \\
\hline HT-25F & {$\left[\mathrm{Mg}_{0.739} \mathrm{Al}_{0.239}(\mathrm{OH})_{1.65} \mathrm{~F}_{0.35}\right]\left(\mathrm{CO}_{3}\right)_{0.119} 0.55 \mathrm{H}_{2} \mathrm{O}$} \\
\hline
\end{tabular}

Characterization. The LDH samples were characterised by X-ray diffraction (XRD), thermal analysis (TGA), infrared (FTIR) spectroscopy and dye adsorption followed by optical spectroscopy.

The XRD patterns were acquired using a diffractometer (D8 Advance-Bruker) coupled to a copper anode X-ray tube. 
Mid-infrared (FTIR) spectra were acquired at room temperature using a Perkin Elmer Series spectrophotometer (Model 6X) operated in the ATR-FTIR mode. The spectra were recorded over the 400$4000 \mathrm{~cm}^{-1}$ spectral window by averaging 32 scans at a resolution of $4 \mathrm{~cm}^{-1}$.

The thermogravimetric analyses were carried out using a thermobalance Q500HR (TA Instruments).

The evaluation of dipolarity/polarisability (parameter $\pi^{*}$ ) of samples was determined by monitoring solvent-dependent shifts of the UV/vis absorption band of 4-tert-butyl-2-(dicyano-methylene)-5-[4(diethylamino)benzylidene]- $\Delta 3$ - thiazoline as the probe dye by means of the multi-parameter method of Kamlet-Taft [23-25] where $\pi^{*}$ is estimated from the UV/vis absorption maxima of adsorbed dye according to: $\pi^{*}=9.475-0.54 v_{\max }\left[10^{-3} \mathrm{~cm}^{-1}\right]$. A spectrometer Perkin-Elmer Lambda 40 was used to acquire the UV-vis powder spectra in reflection mode. Dye containing samples spectra were recorded with dye-free powders as a reference.

THMs uptake by layered double hydroxides. All the sorption experiments were performed in batch at room temperature $\left(22^{\circ} \mathrm{C}\right)$, using fresh or calcined LDHs. The ratio mass of adsorbent to volume of solution was fixed to $12.5 \mathrm{mg} / \mathrm{ml}$. For each experimental run, $10 \mathrm{ml}$ aqueous solution of the THM was taken in a $50 \mathrm{ml}$ vessel containing $0.125 \mathrm{~g}$ of the adsorbent. Suspensions were agitated at $150 \mathrm{rpm}$. At the end of the predetermined time, $t$, the suspensions were centrifuged, and the supernatant analysed for THM concentration by ${ }^{1} \mathrm{H}$ NMR. ${ }^{1} \mathrm{H}$ NMR spectra were acquired in a Bruker Avance 400 NMR spectrometer, operating at $400 \mathrm{MHz}$. The samples were loaded in a $5 \mathrm{~mm} \mathrm{NMR}$ tube using $\mathrm{CDCl}_{3}$ with TMS reference as solvent. The signal at $7.2 \mathrm{ppm}$, corresponding to chloroform was integrated and the concentration calculated by comparing to integrated signal of reference. The same method was applied to monitoring $\mathrm{CHBr}_{3}$, integrating the signal at $6.8 \mathrm{ppm}$.

\section{Results and discussion}

\section{Adsorbents}

X-ray diffraction patterns of the fresh samples are displayed in Fig. 1. In three samples the hydrotalcite phase (JCPDS card 22-0700) was indexed and no crystalline fluorine compounds were identified. The degree of crystallization is low as frequently is observed in samples prepared by sol-gel. Because of the broadness of XRD peaks is hard to confirm any influence of the presence of fluorine on the position of (003) peak. Earlier [26], in samples of LDH prepared by sol gel was demonstrated that samples exhibited broad XRD peaks the total amount of $\mathrm{Al}$ is incorporated to the $\mathrm{LDH}$ lattice and consequently brucite is not formed.

Fig. 2 shows the FTIR spectra of layered samples where the absorption band due to the $\mathrm{O}-\mathrm{H}$ stretching is observed from 3700 to $3000 \mathrm{~cm}^{-1}$. The intensity of this band is modified with the presence or the absence of fluorine. Actually, infrared intensities of the broad $\mathrm{OH}$ stretching bands were integrated by using the EZ OMNIC 32 software. The integrated intensities were 1310, 1223, and 1011 for HT, HT-10F, and HT$25 \mathrm{~F}$, respectively. These values support the replacement of $\mathrm{OH}^{-}$by $\mathrm{F}^{-}$, as previously reported in the synthesis of fluorinated LDH by coprecipitation. The band attributed to the bending deformation of molecular water is observed at $1650 \mathrm{~cm}^{-1}$. The band assigned to the asymmetric stretching of $\mathrm{C}-\mathrm{O}$ bonds in carbonate ions [2728 ] is observed between 1340 and $1450 \mathrm{~cm}^{-1}$. A fact that should be emphasized is the presence of a band at $1554 \mathrm{~cm}^{-1}$ which is assigned to monodentate carbonate species, this band is stronger in spectra HT and HT$10 \mathrm{~F}$ than in spectrum of sample HT-25F. This monodentate carbonate species have been related with the presence of strong basic sites [29]. Thus, it seems that fluorination of brucite-like layers have eroded strong basic $\mathrm{OH}^{-}$sites, since some of this $\mathrm{OH}^{-}$groups were changed by $\mathrm{F}^{-}$. 


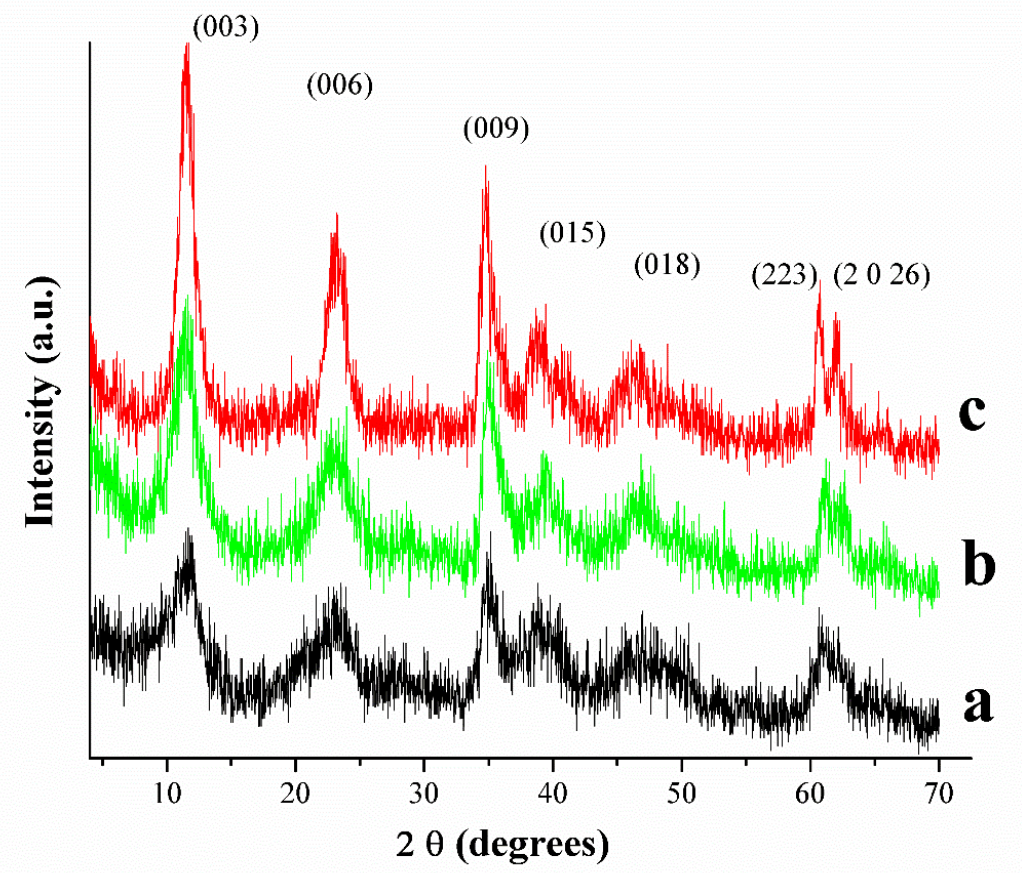

Fig. 1. X-ray diffraction patterns of LDH as synthesized: (a) HT, (b) HT-10F and (c) HT-25F. Peak labels indicate Miller index of JPCDS card 22-0700.

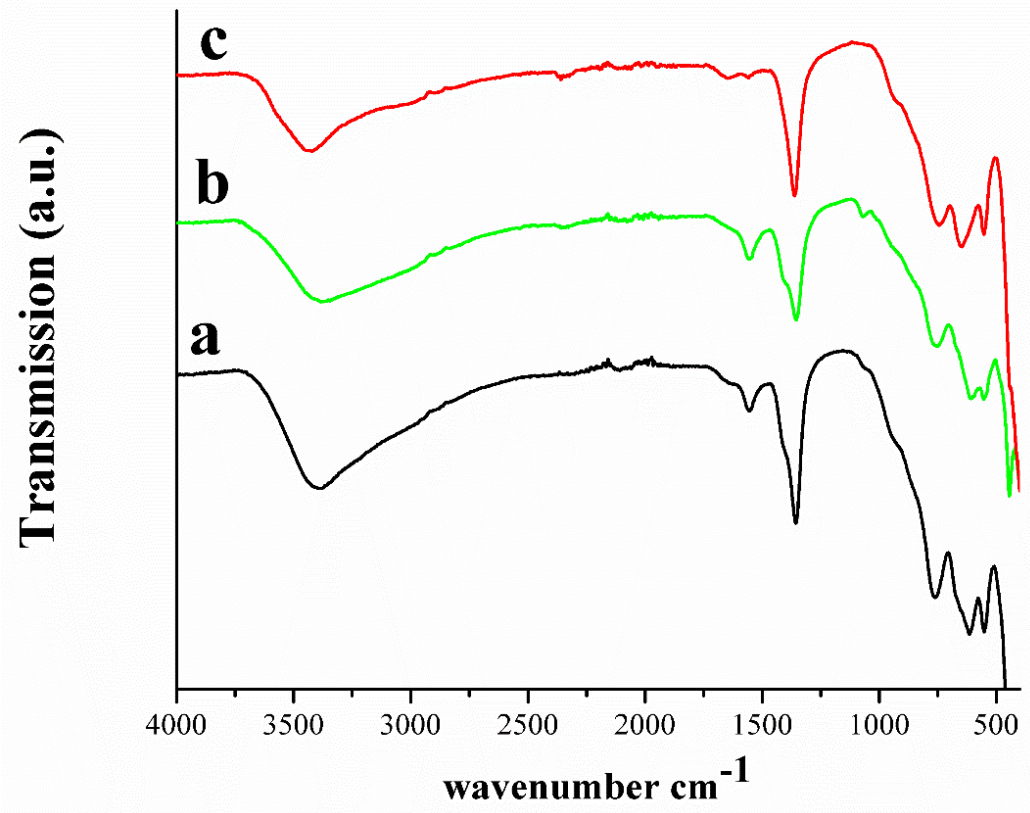

Fig. 2. Infrared spectra of LDH as synthesized: (a) HT, (b) HT-10F and (c) HT-25F. 
Fig. 3 displays representative UV/vis absorption spectra of dye adsorbed on the thermal treated LDH samples. The position of absorption band is dependent of the composition of sample, the higher the fluorine content the higher the wave length. From these spectra, the $\pi^{*}$ values for solids HT, HT-10F, and HT-25F were $0.99,1.18$ and 1.27 , respectively. Clearly, the presence of fluorine increases the dipolarity/polarisability at surface of LDH which is explained because the different electronegativity of $\mathrm{F}$ and $\mathrm{O}$ atoms leads to formation of dipoles differing in magnitude and orientation. The replacement $\mathrm{OH}^{-}$by $\mathrm{F}^{-}$is aleatory trough the bulk and surface of LDH. However, the presence of fluorine content affects the stacking of layers leading to materials differing in morphology as shown in SEM images in Fig. 4. The particles of sample without fluorine have an irregular shape. Small particles agglomerates lying on top of one another can be observed to form particles as big as $80 \mu \mathrm{m}$. In contrast, in samples containing fluorine the layers are aggregated to form particles smaller than $40 \mu \mathrm{m}$.

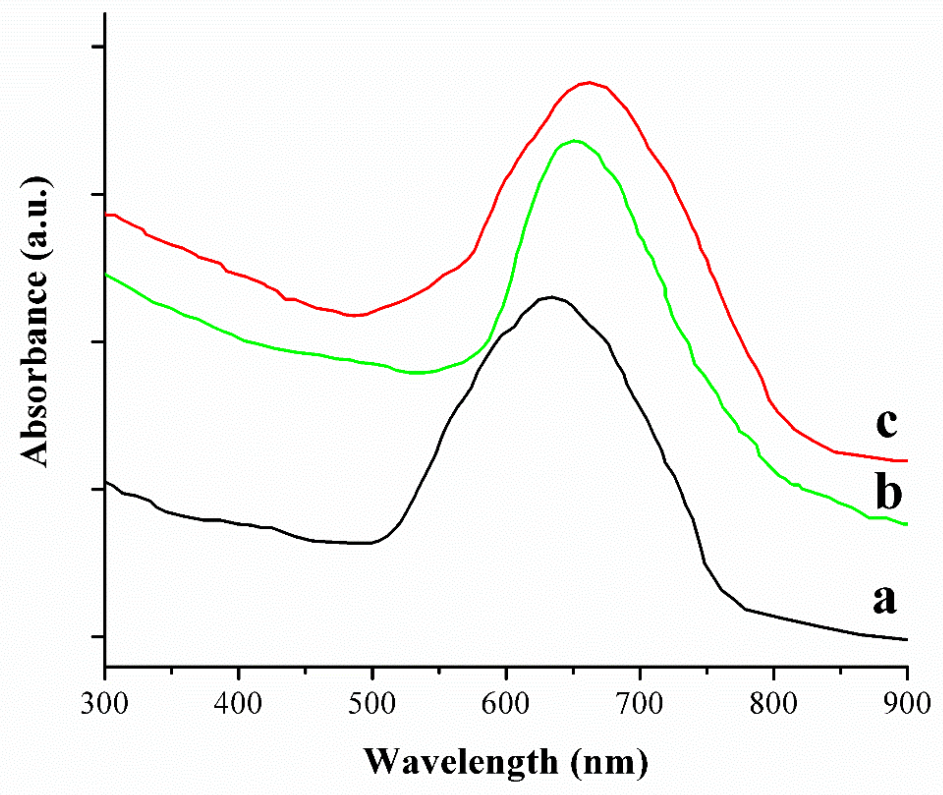

Fig. 3. UV-vis spectra of the solvatochromic dye 4-tert-butyl-2-(dicyano-methylene)-5-[4(diethylamino)benzylidene]- $\Delta 3$-thiazoline adsorbed onto (a) HT, (b)HT-10F and (c) HT-25F.
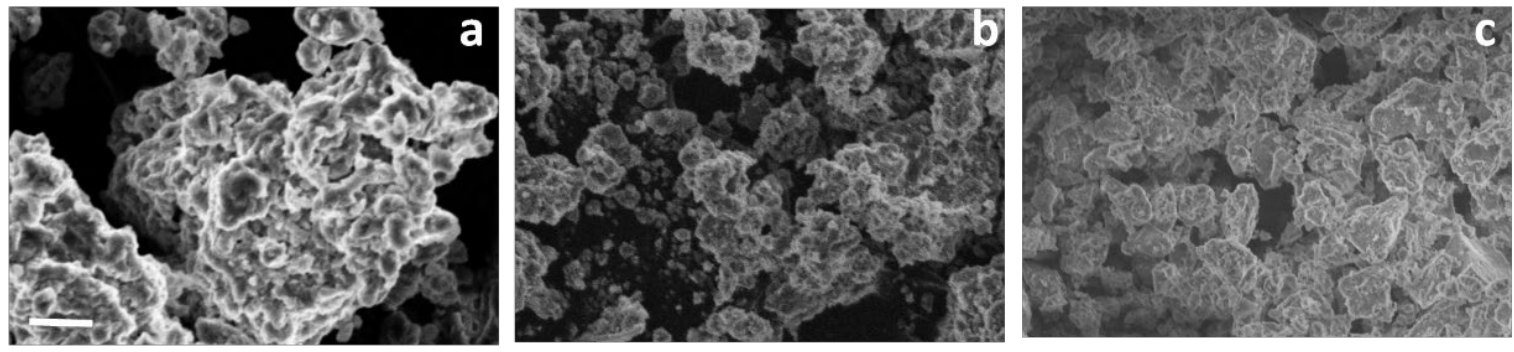

Fig. 4. SEM image of (a) HT, (b) HT-10F and (c) HT-25F. The bar scale in image (a) corresponds to $20 \mu \mathrm{m}$ and it is valid for all three images. 
In summary, the fluorination of brucite-like layers leads to materials with different dipoles at surfaces prone to stabilize dipolar and polarizable molecules. So, the following section is intended to explore the potential retention of trihalomethanes in fluorinated LDH trough dipolar interactions sorbate-adsorbent.

\section{Thrihalomethanes adsorption}

Adsorption equilibrium time. The time-dependent curves of THM solution concentration in contact with different adsorbents are shown in Fig. 5. The concentration of $\mathrm{CHCl}_{3}$ decreases significantly in 10 first minutes of contact with adsorbent. The major decreasing in solution concentration during first 10 minutes was observed when the adsorbents used were the samples containing fluorine. Further, it is clear that fresh samples adsorb less THM than the thermal treated ones. After ten minutes, the adsorption on LDHs continues slowly and after 20 minutes it can be assumed that the equilibrium $\mathrm{CHCl}_{3(\mathrm{aq})}+\mathrm{LDH}_{(\mathrm{sol})} \leftrightarrow$ $\left(\mathrm{LDH}_{\mathrm{x}} \mathrm{CHCl}_{3}\right)_{(\mathrm{sol})}+(1-\mathrm{x}) \mathrm{CHCl}_{3(\mathrm{aq})}$ was reached.
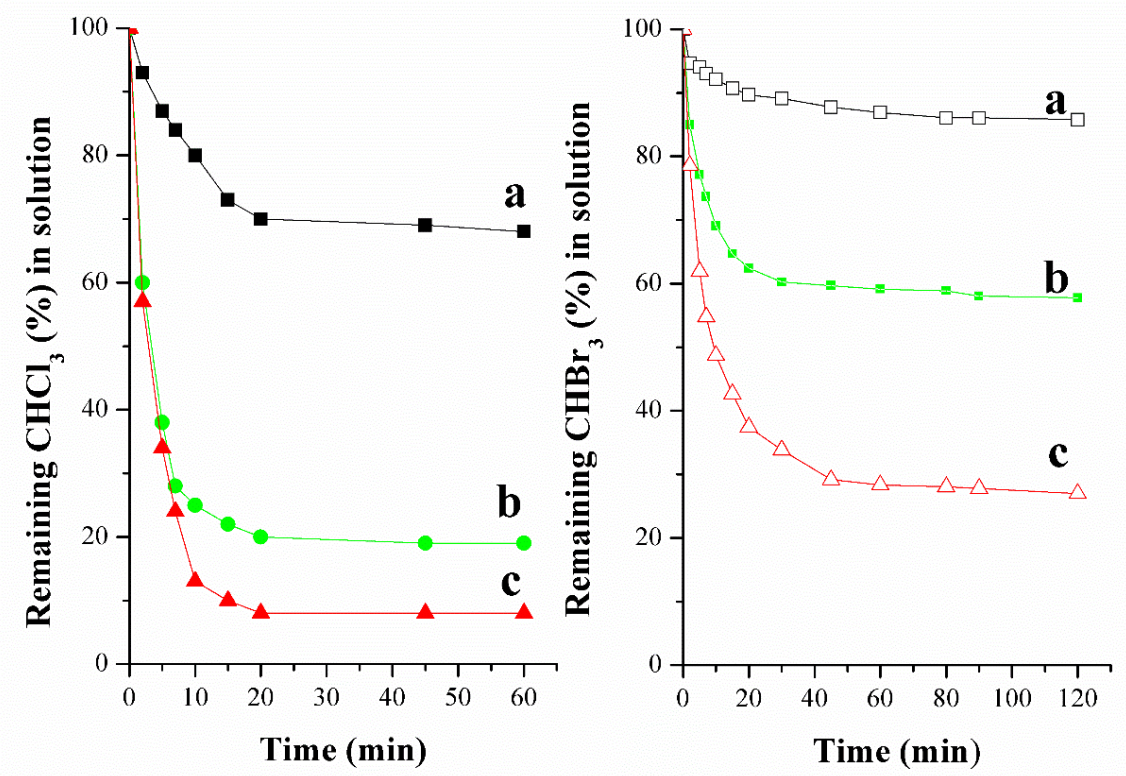

Fig. 5. Concentration progress of $\mathrm{CHCl}_{3}$ (left) and $\mathrm{CHBr}_{3}$ (right) after contact with different adsorbents (a) HTC, (b) HT-10FC and (c) HT-25FC. Initial concentration of $\mathrm{CHCl}_{3}$ and $\mathrm{CHBr}_{3}$ was $5 \times 10^{-3}$ and $4 \times 10^{-4} \mathrm{M}$, respectively. Adding of $\mathrm{C}$ to code sample means that adsorbent was thermal treated at $350{ }^{\circ} \mathrm{C}$ for $8 \mathrm{~h}$. The ratio mass of adsorbent to volume of solution was fixed to $12.5 \mathrm{mg} / \mathrm{ml}$.

The adsorption experiments made with $\mathrm{CHBr}_{3}$ progressed slower than that with $\mathrm{CHCl}_{3}$. Again, the curves show a first period of 10 minutes were the solution concentration diminishes significantly but, differently to $\mathrm{CHCl}_{3}$, the concentration continues decreasing for periods as long as 90 minutes, thus this time was taken as the equilibrium time. Even when the initial concentrations of $\mathrm{CHCl}_{3}$ and $\mathrm{CHBr}_{3}$ were not the same, results in the next sections will confirm that nature of the THM is very influent in the adsorption progression. The different concentrations were taken because of the different solubility of THM and the goal in this study to explore removal of THM at low concentration.

The effect of the composition and structure of adsorbent. In Fig. 6 is plotted the percent of $\mathrm{CHCl}_{3}$ removal trough adsorption onto different adsorbents. Clearly, the solids thermally treated previous to adsorption remove the major fraction of chloroform which is explained because the presence of numerous polar sites present at surface of thermally treated samples [22]. This trend is observed also when the adsorbat 
is $\mathrm{CHBr}_{3}$. Thus, the high specific surface area and major number of polar sites in adsorbate enhance the adsorption of $\mathrm{CHCl}_{3}$ and $\mathrm{CHBr}_{3}$.
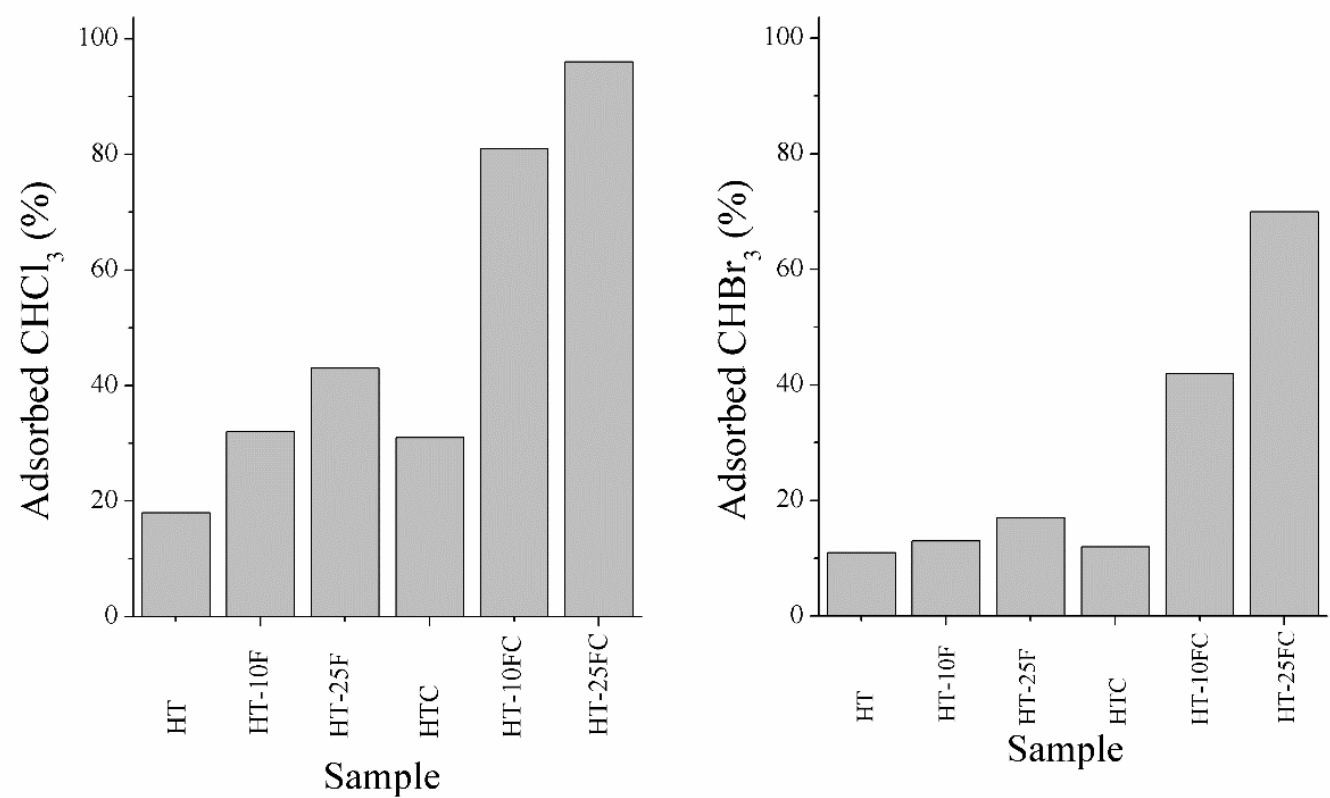

Fig. 6. $\mathrm{CHCl}_{3}$ (left) and $\mathrm{CHBr}_{3}$ (right) removal efficiency through adsorption on different adsorbents. The equilibrium time was taken as 30 and 90 minutes for $\mathrm{CHCl}_{3}$ and $\mathrm{CHBr}_{3}$, respectively.

Independently of the adsorbent, fresh or thermal treated, the presence of fluorine in adsorbents clearly increases the capacity of adsorbed THM. For example, the sample HT25FC removes $97 \%$ of $\mathrm{CHCl}_{3}$ in solution but the free-fluorine adsorbent only eliminates $33 \%$ of $\mathrm{CHCl}_{3}$ initially present in solution.

Another highlighted observation is that percentage of $\mathrm{CHCl}_{3}$ removed by adsorption on $\mathrm{LDH}$ is higher than that observed for $\mathrm{CHBr}_{3}$. The dipole moment of $\mathrm{CHCl}_{3}(1.122 \mathrm{D})$ is slightly higher than that of $\mathrm{CHBr}_{3}(0.99 \mathrm{D})$. Further, $\mathrm{CHBr}_{3}$ is bigger than $\mathrm{CHCl}_{3}$, thus, this differences limit the dipole interactions with polar sites at surface of adsorbents.

The effect of the initial THM concentration solution. The adsorption of $\mathrm{CHCl}_{3}$ onto $\mathrm{LDHs}$ was measured at different $\mathrm{CHCl}_{3}$ concentrations in the range from $5 \times 10^{-3}$ to $5 \times 10^{-2} \mathrm{M}$. Results are presented in Fig. 7. It is clear that the initial concentration is a significant driving force to prevail over all mass transfer resistance of $\mathrm{CHCl}_{3}$ between the aqueous and solid phases. Thus, a higher initial concentration of $\mathrm{CHCl}_{3}$ increased adsorption of $\mathrm{CHCl}_{3}$. This result was consistent for shortest periods (first 10 minutes) and for all adsorbents. Some remarks have to be enumerated: 1) the adsorbent without fluorine is the one with the lowest adsorption capacity. In this material series an initial $\mathrm{CHCl}_{3}$ concentration of $5 \times 10^{-3} \mathrm{M}$ leads to a removal of $\mathrm{CHCl}_{3}$ through adsorption as low as $28 \%$. With increase of $\mathrm{CHCl}_{3}$ concentration the adsorptivity increases until removal $58 \%$ of THM when the initial concentration is 0.05 M. 2) the rate of adsorption and the adsorption capacity of fluorinated adsorbents is significantly higher than that of the free-fluorine adsorbents. The adsorbent HT10FC removes after 20 minutes 78, 82, 89 and $95 \%$ of the $\mathrm{CHCl}_{3}$ when the initial $\mathrm{CHCl}_{3}$ concentration is $5 \times 10^{-3}, 2 \times 10^{-2}, 3 \times 10^{-2}$ and $5 \times 10^{-3} \mathrm{M}$, respectively. On the other hand, the adsorbent with the highest loading of fluorine is the best adsorbent, taking in the first 10 minutes more than $94 \%$ of $\mathrm{CHCl}_{3}$ present initially in solution, independently of the initial $\mathrm{CHCl}_{3}$ concentration. 3) The high capacity of adsorption showed by fluorinated LDHs suggest that number of adsorption sites is modified with 
the fluorination. Further, the saturation of adsorption sites does not occur as the concentration of $\mathrm{CHCl}_{3}$ is low in order to reach $\mathrm{CHCl}_{3}$ concentrations measured in drinking and swimming pool water.

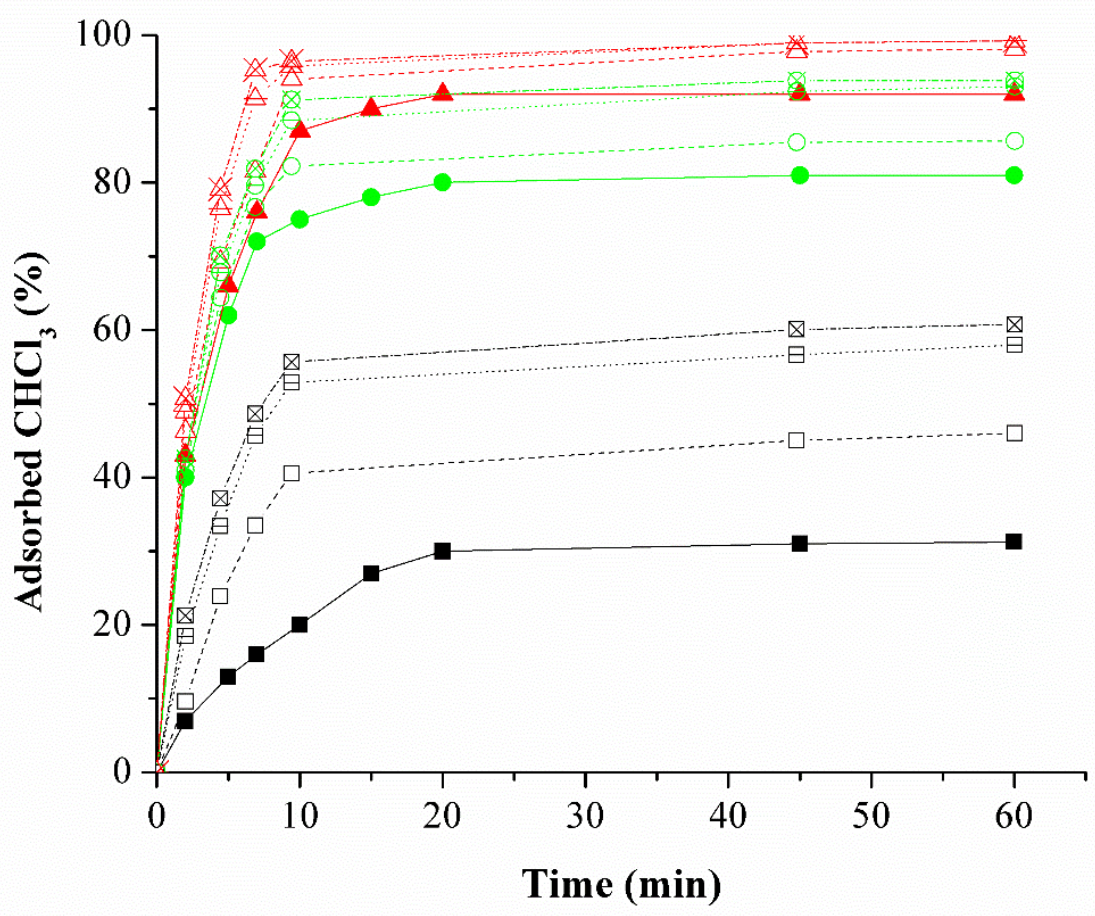

Fig. 7. $\mathrm{CHCl}_{3}$ adsorption onto different adsorbents (squares) HTC, (circles) HT-10FC and (triangles) HT$25 \mathrm{FC}$, starting with different initial $\mathrm{CHCl}_{3}$ concentration, $5 \times 10^{-3} \mathrm{M}$ (solid lines), $2 \times 10^{-2}$ (dashed lines), $3 \times 10^{-2}$ (dotted lines), $5 \times 10^{-2}$ (dotted-dashed lines).

In Fig. 8 are contained the results of $\mathrm{CHBr}_{3}$ adsorption on un-fluorinated and fluorinated LDHs as a function of initial $\mathrm{CHBr}_{3}$ concentration. In line with the behavior observed with $\mathrm{CHCl}_{3}$, the percent of $\mathrm{CHBr}_{3}$ retained on weight unit of adsorbent increase with the increasing of initial $\mathrm{CHBr}_{3}$ concentration from aqueous solution. Starting from $\mathrm{CHBr}_{3} 4 \times 10^{-4} \mathrm{M}$ and $5 \times 10^{-3} \mathrm{M}$ the best adsorbent was $\mathrm{HT} 25 \mathrm{FC}$ adsorbing close to $70 \%$ and $90 \%$ of $\mathrm{CHBr}_{3}$, respectively. For the same initial $\mathrm{CHBr}_{3}$ concentration, the efficiency of $\mathrm{CHBr}_{3}$ removal follows the order: $\mathrm{HT} 25 \mathrm{FC}>\mathrm{HT} 10 \mathrm{FC}>\mathrm{HTC}$. However, it is clear that $\mathrm{CHBr}_{3}$ adsorption proceeds less efficient than that observed for $\mathrm{CHCl}_{3}$. As shown in previous section, the $\mathrm{CHBr}_{3}$ adsorption proceeds slowly than $\mathrm{CHCl}_{3}$ adsorption. Thus, it seems that this trend is determined by the fact that at higher concentrations, the most superficial groups are already occupied and in consequence, the diffusion of $\mathrm{CHBr}_{3}$ to the un-reacted functional groups is inhibited. Note that, saturation of adsorption sites is not an alternative explanation as with $\mathrm{CHCl}_{3}$ adsorption enhanced with concentrations as high as $0.05 \mathrm{M}$. Thus, the effect observed in $\mathrm{CHBr}_{3}$ should be attributed to the size of molecule inhibiting motion during adsorption. 


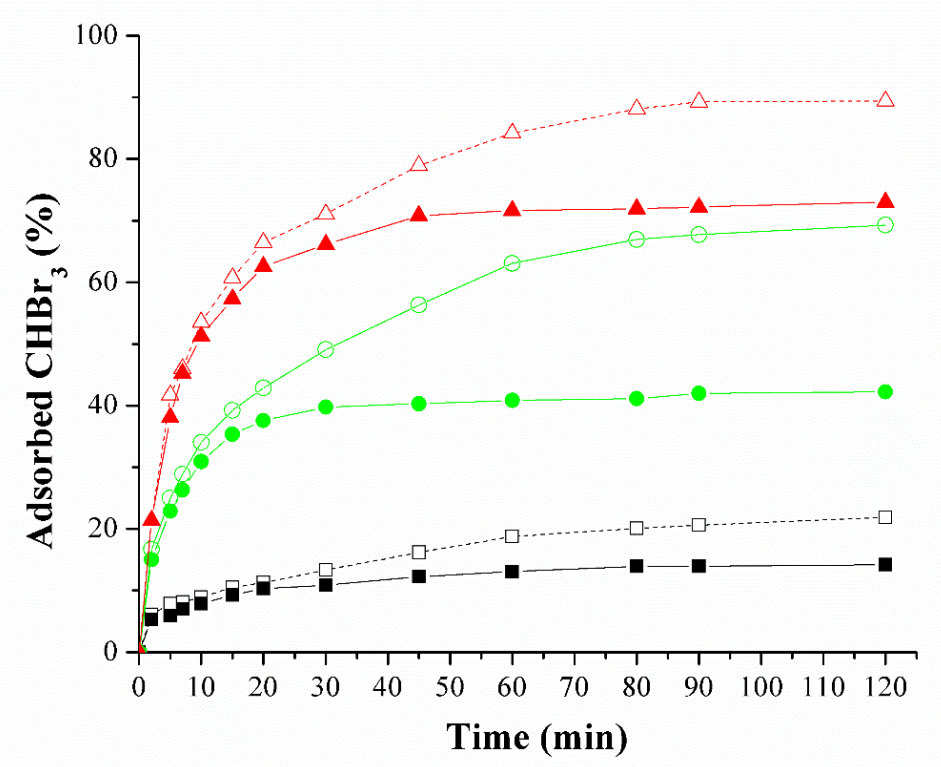

Fig. 8. $\mathrm{CHBr}_{3}$ adsorption onto different adsorbents (squares) HTC, (circles) HT-10FC and (triangles) HT$25 \mathrm{FC}$, starting with different initial $\mathrm{CHCl}_{3}$ concentration, $4 \times 10^{-4} \mathrm{M}$ (solid lines), $5 \times 10^{-3}$ (dashed lines).

Adsorption isotherm. The isotherms plotted in Fig. 9 point out the effect of the presence of fluorine in adsorbents. Linear profiles, $\mathrm{q}_{\mathrm{e}}=\mathrm{kCe}$, are obtained when adsorbents do not contain fluorine, which is often observed in cases where adsorbat concentration is low. Interesting, the isotherm of both $\mathrm{CHCl}_{3}$ and $\mathrm{CHBr}_{3}$ match to that of Freundlich's model, $\mathrm{q}_{\mathrm{e}}=\mathrm{K}(\mathrm{Ce})^{1 / \mathrm{n}}$, when the adsorbent contains fluorine. Further, in both Freundlich isotherms $1 / n>1$, which means that THM adsorbs forming a mono layer onto adsorbent. Currently, the observed isotherms are obtained for polar compounds. Both $\mathrm{CHCl}_{3}$ and $\mathrm{CHBr}_{3}$ have a dipolar moment and, at low concentrations, such compounds are in competition with water for adsorption sites of adsorbent. Of course the adsorption sites should be also polar groups. Clearly, the adsorption of THM is more favorable in fluorinated adsorbents and this feature is explained because of the major polarity induced by the presence of fluorine.
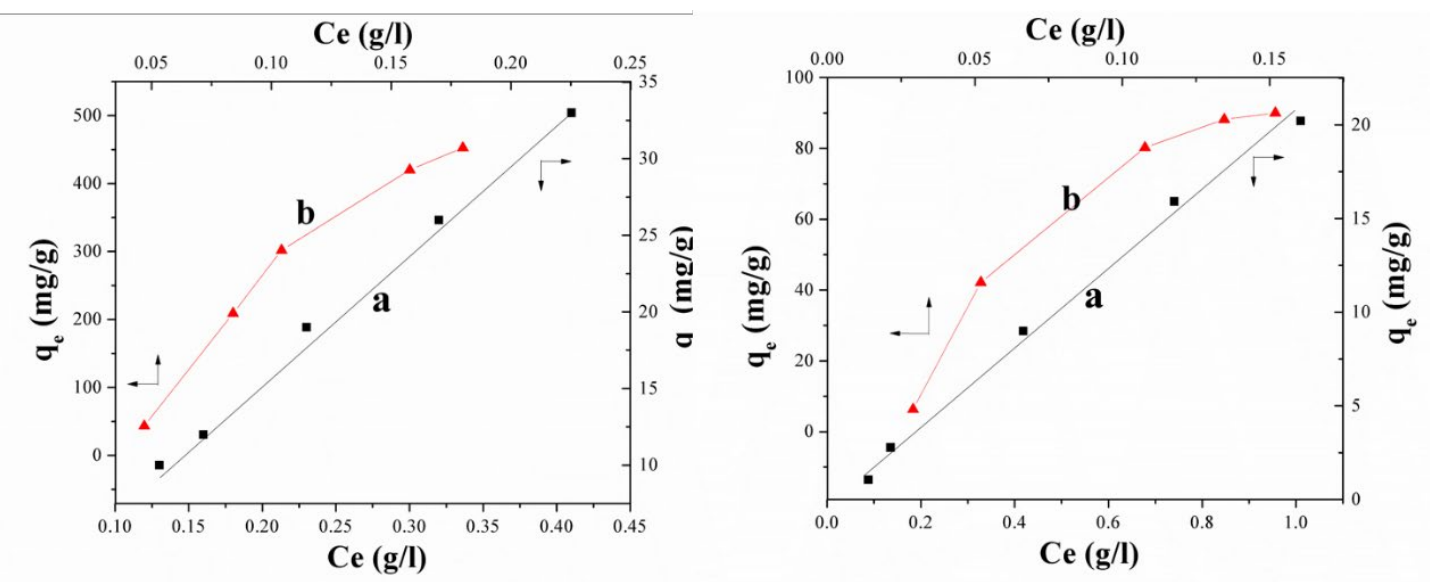

Fig. 9. Adsorption isotherms of $\mathrm{CHCl}_{3}$ (left) and $\mathrm{CHBr}_{3}$ (right) onto (a) HTC, and (b) HT-25FC. qe represents the amount of THM per unit mass of adsorbent and Ce the equilibrium concentration of the remaining THM in solution. The equilibrium time was taken as 30 and 90 minutes for $\mathrm{CHCl}_{3}$ and $\mathrm{CHBr}_{3}$, respectively. 


\section{Conclusion}

Fluorination of layered double hydroxides was carried out replacing $\left(\mathrm{AlOH}_{6}\right)^{3-}$ blocks by $\left(\mathrm{AlF}_{6}\right)^{3-}$ during a sol gel process. The presence of fluorine in LDHs enhanced the dipolarity/polarizability properties at surface of these materials. As a consequence of the major dipolarity, the capacity to adsorb trihalomethanes increased. Fluorinated LDHs are able to remove $95 \%$ of $\mathrm{CHCl}_{3}$ present at low concentration in water $\left(3 \times 10^{-2}\right.$ $\mathrm{M})$ and to remove $90 \%$ of $\mathrm{CHBr}_{3}$ dissolved $5 \times 10^{-3} \mathrm{M}$ in water. The type of isotherm adsorption was function of the adsorbent independently of the THM. Linear adsorption profiles were obtained using un-fluorinated adsorbents and the isotherms turn to be Freundlich-type when adsorbent contains fluorine.

\section{Acknowledgments}

This work was financially supported by CONACYT (Grant 220436) and PAPIIT-IN106517. We are also grateful to G. Cedillo and A. Tejeda for their technical assistance.

\section{References}

1. Yang, Y; Ok, Y. S.; Kim, K. H.; Kwon, E. E.; Tsang, Y. F. Occurrences and removal of pharmaceuticals and personal care products (PPCPs) in drinking water and water/sewage treatment plants: A review. Science of The Total Env. 2017, 596-597, 303-320.

2. U.S. Environmental Protection Agency (U.S. EPA), 2012a. Impaired Waters and Total Maximum Daily Loads.

3. Arnone, R.D.; Walling, J.P. Waterborne pathogens in urban watersheds, J. Water Health .2007, 5 , 149-162

4. Hodgeson, J.W.; Cohen, A.L.; Munch, D.J. Determination of Chlorination Disinfection byproducts, Chlorinated Solvents, and Halogenated Pesticides/herbicides in Drinking Water by Liquid-liquid Extraction and Gas Chromatography with Electron Capture Detection. EPA, Cincinnati USA, 1990.

5. Lantagne, D.S.; Blount, B.C.; Cardinali, F.; Quick, R. Disinfection by-product formation and mitigation strategies in point-of-use chlorination of turbid and non-turbid waters in western Kenya. $J$. Water Health. 2008, 6, 67-82.

6. Gopal, K.; Tripathy, S.S.; Bersillon, J.L.; Dubey, S.P. Chlorination byproducts, their toxicodynamics and removal from drinking water, J. Hazard. Mater. 2007,140, 1-6.

7. Verma, K.; Guptab, A.B.; Sing, A. Optimization of chlorination process and analysis of THMs to mitigate ill efects of sewage irrigation. J. Env. Chem. Eng. 2017, 5, 3540-3549.

8. Filloux; E.; Gallard, H.; Croué, J.-P. Identification of effluent organic matter fractions responsible for low-pressure membrane fouling. Water Res. 2012 46, 5531-5540.

9. Gan, X.; Karanfil, T.; Kaplan Bekaroglu, S.S.; Shan, J. The control of N-DBP and C-DBP precursors with MIEX®, Water Res. 2013, 47, 1344-1352.

10. Gan, X.; Kim, D.; Karanfil, T. MIEX treatment of an effluent-impacted stream. J. Am. Water Works Assoc. 2013, 105, E195-E206.

11. T.V. Nguyen, R. Zhang, S. Vigneswaran, H.H. Ngo, J. Kandasamy, P. Mathes, Removal of organic matter from effluents by magnetic ion exchange (MIEX®). Desalination. 2011, 276, 96-102.

12. Wang, J.; Li, H.; Li, A.; Shuang, C.; Zhou, Q. Dissolved organic matter removal by magnetic anion exchange resin and released ion elimination by electrolysis. Chem. Eng. J. 2014, 253, 237-242.

13. Miyata, S. Physico-chemical properties of synthetic hydrotalcites in relation to composition Clays. Clay Minerals. 1980, 28, 50-56.

14. Meyn, M. ; Beneke, K. ; Lagaly, G. Anion-exchange reactions of layered double hydroxides. Inorg. Chem. 1990, 29, 5201-5207.

15. Rius, J.; Plana, F. Contribution to the superstructure resolution of the double layer mineral motukoreaite. Neues Jahrbuch fur Mineralogie Monatshefte.1986, 263-272. 
16. Choy, J.-H.; Jung, J.-S.; Oh, J.-M. ; Jeong, M. Park.; J.; Kang, Y.-K.; Han, O.-J. Layered double hydroxide as an efficient drug reservoir for folate derivatives. Biomater. 2004, 25, 3059-3064

17. Nakayama, H.; Wada, N.; Tsuhako, M. Intercalation of amino acids and peptides into Mg-Al layered double hydroxide by reconstruction method. Int. J. Pharm. 2004, 269, 469-478.

18. Stanimirova, T.S.; Kirov, G.; Donolova, E.J. Mechanism of hydrotalcite regeneration. Mater. Sci. Lett. 2001, 20, 453-455.

19. Li C.; Wei, M.; Evans, D. G.; Duan, X. Layered Double Hydroxide-based Nanomaterials as Highly Efficient Catalysts and Adsorbents. Small. 2014, 10, 4469-4486.

20. Laguna, H; Ibarra, I.; Loera, S.; Lima, E.; Lara, V. Hydrotalcite-Like Compounds Hosting Azoic Dyes: Non Toxic Hybrid Pigments. Micr. Mes. Mater. 2007, 98, 234-241.

21. Lima, E.; Martínez-Ortiz, M. J.; Gutiérrez Reyes, R.I.; Vera, M. Fluorinated Hydrotalcites: The Addition of Highly Electronegative Species in Layered Double Hydroxides To Tune Basicity. Inorg. Chem. 2012, 51, 7774-7781.

22. Lima, E.; Pfeiffer, H.; Flores, J. Some consequences of the fluorination of brucite-like layers in layered double hydroxides: Adsorption. Appl. Clay. Sc. 2014, 88-89, 26-32.

23. Spange, S.; Zimmermann, Y.; Graeser, A. Hydrogen-Bond-Donating Acidity and Dipolarity/Polarizability of Surfaces within Silica Gels and Mesoporous MCM-41 Materials. Chem. Mater. 1999, 11, 3245-3251

24. Spange, S.; Schmidt, C.; Kricheldorf, H. R. Probing the Surface Polarity of Poly( $\alpha$-amino acids) and $\alpha$-Amino Acid Crystals with Genuine Solvatochromic Dyes. Langmuir. 2001, 17, 856-865.

25. Spange, S.; Prause, S.; Vilsmeier, E.; Thiel, W.R. Probing surface basicity of solid acids with an aminobenzodifurandione dye as the solvatochromic probe. J. Phys. Chem. B. 2005, 109, 7280-7289.

26. Lopez, T.; Bosch, P.; Ramos, E.; Gomez, R.; Novaro, O.; Acosta, D.; Figueras, F. Synthesis and Characterization of Sol-Gel Hydrotalcites. Structure and Texture. Langmuir. 1996, 12, 189-192.

27. Lavalley, J. C. Infrared spectrometric studies of the surface basicity of metal oxides and zeolites using adsorbed probe molecules. Catal. Today. 1996, 27, 377-401.

28. Sampieri, A.; Lima, E. On the Acid- Base Properties of Microwave Irradiated Hydrotalcite-like Compounds Containing $\mathrm{Zn}^{2+}$ and $\mathrm{Mn}^{2+}$. Langmuir. 2009, 25, 3634-3639.

29. Tsuji, H.; Okamura-Yoshida, A.; Shishido, T.; Hattori, H. Dynamic Behavior of Carbonate Species on Metal Oxide Surface: Oxygen Scrambling between Adsorbed Carbon Dioxide and Oxide Surface. Langmuir. 2003, 19, 8793-8800. 